\title{
ELECTRICAL CONDUCTIVITY, ION-MOLECULAR AND INTERIONIC INTERACTIONS IN SOLUTIONS OF SOME TETRAALKYLAMMONIUM SALTS IN ACETONITRILE: THE INFLUENCE OF THE ION AND TEMPERATURE
}

\author{
O.N. Kalugin ${ }^{\text {a }}$, E.V. Lukinova ${ }^{b}$, D.O. Novikov ${ }^{c}$
}

V.N. Karazin Kharkiv National University, School of Chemistry, Department of Inorganic Chemistry 4 Svobody sqr., 61022 Kharkiv, Ukraine
a) onkalugin@gmail.com
b) $\bowtie$ elena.v.lukinova@gmail.com
c) $₫$ dmitrynovikovs@gmail.com

\author{
(D) https://orcid.org/0000-0003-3273-9259 \\ (D) https://orcid.org/0000-0002-8016-0439 \\ (1) https://orcid.org/0000-0003-3584-4521
}

Conductance data for $\mathrm{Et}_{4} \mathrm{NBr}, \mathrm{Et}_{4} \mathrm{NBF}_{4}, \mathrm{Bu}_{4} \mathrm{NBr}, \mathrm{Bu}_{4} \mathrm{NBF}_{4}$ in acetonitrile for the molar concentration range of $2 \cdot 10^{-4}-1 \cdot 10^{-2} \mathrm{~mol} \cdot \mathrm{dm}^{-3}$ over the temperature range from 5 to $55^{\circ} \mathrm{C}$ are reported. Limiting molar conductivities and ion association constants were determined by using the Lee-Wheaton equation for the symmetrical electrolytes. On the basis of the preliminary conductometric data analysis it was established that the closest approach parameter is almost independent from the temperature for all studied acetonitrile solutions. Therefore, the closest approach parameter was adopted as a sum of cation and anion radii for further conductometric data treatment.

The limiting conductivities of $\mathrm{Br}^{-}, \mathrm{BF}_{4}^{-}, \mathrm{Et}_{4} \mathrm{~N}^{+}$and $\mathrm{Bu}_{4} \mathrm{~N}^{+}$ions and the structure-dynamic parameter of ionmolecular interaction obtained from the experimental data on limiting molar conductivities were evaluated in the framework of the approach proposed by authors [Kalugin O. N., Vjunnik I. N. Limiting ion conductance and dynamic structure of the solvent in electrolyte solution. Zh. Khim. Fiz. (Rus.) 1991, 10 708-714]. Elongation of the alkyl radical of the tetraalkylammonium cation from $\mathrm{Et}_{4} \mathrm{~N}^{+}$to $\mathrm{Bu}_{4} \mathrm{~N}^{+}$leads to a significant increase in the structure-dynamic parameter, which indicates the dynamic structuring of the solvent near the tetrabutylammonium ion and increased solvophobic solvation of the $\mathrm{Bu}_{4} \mathrm{~N}^{+}$compared to $\mathrm{Et}_{4} \mathrm{~N}^{+}$.

Ion association constants are discussed in terms of competition between Coulomb and non-Coulomb forces in terms of short-range square-mound potential. An increase in the ion association constants in the sequence $\mathrm{Bu}_{4} \mathrm{NBF}_{4}<\mathrm{Et}_{4} \mathrm{NBF}_{4}<\mathrm{Bu}_{4} \mathrm{NBr}<\mathrm{Et}_{4} \mathrm{NBr}$ was explained by the increase in the contribution of short-range ionmolecular interactions to the interionic attraction in addition to the electrostatic component. An increase in temperature enhances the ionic association due to both the electrostatic and short-range components.

Keywords: tetraethylammonium bromide, tetrabutylammonium bromide, tetraethylammonium tetrafluoroborate, tetrabutylammonium tetrafluoroborate, acetonitrile, electrical conductivity, ion association constant, limiting molar conductivity, square-mound interionic potential, ion solvation microdynamics.

\section{Introduction}

Non-aqueous electrolyte solutions are widely used in electrochemical energy storage devices, such as supercapacitors (SCs) with porous nano-carbon electrodes [1]. Non-aqueous solutions of tetraalkylammonium salt-based electrolytes were used to test samples of porous carbon electrodes in SCs [2]. On one hand, non-aqueous solutions of tetraalkylammonium salts have a broader operating current range [3] and a wider operating temperature range, compared to water electrolyte solutions [4-5]. On the other hand, non-aqueous solutions of tetraalkylammonium salts have even greater ionic conductivity than ionic liquids [6-7]. It was also shown that electrical conductivity of symmetrical tetraalkylammonium salts in acetonitrile is greater compared to the corresponding solutions in propylene carbonate, $\gamma$-butyrolactone and dimethylformamide [8]. Moreover, a unique combination of dielectric permittivity, viscosity and solubility in acetonitrile of both solid and liquid electrolytes and ionic liquids (ILs) have caused an extensive use of acetonitrile in electrochemical practice.

Electrolytes for SCs have to satisfy a set of requirements that determine technical and operational characteristics of the electrochemical device: a broad temperature interval of the liquid state, high electrochemical stability and non-hygroscopicity [9]. However, high electrical conductivity of solventelectrolyte system still remains the property of paramount importance.

A literature review shows that the data on electrical conductivity adequately cover many 1-1 electrolytes in acetonitrile, including tetraalkylammonium salts [10-13]. Unfortunately, in most of them either only data at $298.15 \mathrm{~K}$ is given, or is interpreted not deep enough. In the same time, conductome- 
try, as a method of analysis, allows to obtain precious information about ion-ion and ion-molecular environment, electrolyte association constant and quantitative characteristics of ionic solvation. As a result, using conductometry it becomes possible to investigate regularities in the influence of composition and nature of electrolyte solution components on its macroscopic properties.

Giving the fact that solutions of $\mathrm{Et}_{4} \mathrm{NBF}_{4}$ are considered as model electrolyte solutions for SCs [14], within this research we focused on studying the influence of the temperature on the electrical conductivity of tetraalkylammonium salts $\mathrm{R}_{4} \mathrm{NX}\left(\mathrm{R}=\mathrm{Bu}, \mathrm{Et} ; \mathrm{X}=\mathrm{BF}_{4}, \mathrm{Br}\right)$ in acetonitrile. Exceptional attention was paid to quantitative characteristics of ion-ion and ion-molecular interactions when interpreting obtained conductometric data. This data is important not only for systematization of already available data but also to formulate new approaches to optimize properties of electrolyte solutions for SCs.

\section{Experimental Section}

Materials. Tetrabutylammonium tetrafluoroborate was synthesized by the reaction:

$$
\mathrm{Bu}_{4} \mathrm{NOH}+\mathrm{HBF}_{4} \rightarrow \mathrm{Bu}_{4} \mathrm{NBF}_{4}+\mathrm{H}_{2} \mathrm{O}
$$

An excess of tetrafluoroboric acid (up to $\mathrm{pH}=5$ ) was added to the water solution of tetrabutylammonium hydroxide $(\omega=40 \%)$. Precipitated needle crystals were filtered on a glass filter and rinsed by double-distilled water until the filtrate had $\mathrm{pH}=7$. Obtained salt was recrystallized 2 times from benzene with the addition of octane.

Tetrabutylammonium bromide (Sigma-Aldrich, 99\% purity) and tetraethylammonium tetrafluoroborate (Sigma-Aldrich, 98\% purity) were recrystallized 2 times from benzene with the addition of hexane and acetone respectively. Tetraethylammonium bromide was recrystallized 3 times from the waterless ethanol.

Purified salts were dried under vacuum at room temperature for $24 \mathrm{~h}$. Needle crystals were then ground down in the agate mortar and re-dried under vacuum at $55-65^{\circ} \mathrm{C}$ to the constant weight $(\delta \mathrm{m}<0.005 \%)$. Dried salts were stored in the glass weighting bottles in the desiccator dehydrated with $\mathrm{P}_{2} \mathrm{O}_{5}$.

Acetonitrile, previously withstood over dry potassium permanganate, was distilled, collecting the $2^{\text {nd }}$ fraction of the solvent. Collected acetonitrile was distilled 4 more times over $\mathrm{P}_{4} \mathrm{O}_{10}$ in order to remove remaining water [15]. In order to remove polyphosphoric acids acetonitrile was boiled with calcined potassium carbonate for 90 minutes. Trace quantities of water were removed by storing acetonitrile over calcium hydride for $12 \mathrm{~h}$ followed by the distillation. The purity of acetonitrile was controlled by specific electrical conductivity $\left(1.1-2.5 \cdot 10^{-8} \mathrm{~S} \mathrm{~cm}^{-1}\right.$ at $\left.25^{\circ} \mathrm{C}\right)$.

Measurements. Initial concentrated solutions for conductometric study were prepared from the solid salt. The rest of the solutions were prepared by diluting the concentrated solution by mass taking into account Archimedes force correction. Molar concentrations of solutions prepared were calculated by the equation (1).

$$
c_{i}=\tilde{m}_{i} \cdot d_{i}(T)
$$

where $d_{i}(T)$ is the density of a solution at a given temperature, $\tilde{m}$ is the concentration of a solution, expressed in moles per $\mathrm{kg}$ of the solution (malonity). $d_{i}(T)$ was found by the equation (2)

$$
d(T)=d_{0}(T)+B \tilde{m}
$$

where $d_{0}$ is the density of a pure solvent, $B$ is the density concentration coefficient.

Experimental densities of the solutions of $\mathrm{Bu}_{4} \mathrm{NBF}_{4}, \mathrm{Bu}_{4} \mathrm{NBr}$ and $\mathrm{Et}_{4} \mathrm{NBF}_{4}$ in acetonitrile were obtained for the concentration range of $0-1 \mathrm{~mol} \mathrm{~kg}^{-1}$ and fitted by equation (2).

The permanence of $B$ coefficient was observed for all solutions studied in the temperature range of $25-55^{\circ} \mathrm{C}$. Therefore, $0.072,0.084$ and $0.066 \mathrm{~kg}\left(\mathrm{~mol} \mathrm{dm}^{3}\right)^{-1}$ values of $B$ coefficient were used for $\mathrm{Bu}_{4} \mathrm{NBF}_{4}, \mathrm{Bu}_{4} \mathrm{NBr}$ and $\mathrm{Et}_{4} \mathrm{NBF}_{4}$ respectively. The value of $B=0.070 \mathrm{~kg}(\mathrm{~mol} \mathrm{dm})^{3}$ for $\mathrm{Et}_{4} \mathrm{NBr}$ in acetonitrile was taken from the literature [16].

The electrical resistance of solutions was measured at $5,15,25,35,45$ and $55^{\circ} \mathrm{C}$ in four doubleelectrode conductometric cells using P5083 and Gwinstek LCR-821 AC bridges. Conductometric cells were previously calibrated against potassium chloride solutions. When measuring the resistance of solutions, conductometric cells were thermostated with the accuracy of $\pm 0.02^{\circ} \mathrm{C}$ for 20 minutes before taking the measurements. 
Obtained values of the solutions' resistance were used to derive specific $\left(\kappa, \mathrm{S} \mathrm{cm}^{-1}\right)$ and molar $\left(\Lambda, \mathrm{S} \mathrm{cm}^{2} \mathrm{~mol}^{-1}\right)$ electrical conductivities. Specific and molar electrical conductivities were calculated taking into account the conductivity of a pure acetonitrile. Obtained primary data is given in Appendix A.

\section{Data Treatment}

A joint approach of conductometric data treatment was used to process experimental data [17]. The approach is based on the application of non-linear least squares method to solve the overfilled system of the equations: concentration dependence of electrical conductivity ( $\left.\Lambda^{\text {theor }}\right)(3)$, the mass action law (4), mass balance equation (5) and expression for mean ionic activity coefficient (6) for a set of $k$ experimental points:

$$
\begin{gathered}
\Lambda^{\text {theor }}=\frac{c_{ \pm}}{c} f\left(c ; \Lambda_{0} ; R\right) \\
K_{A}=c_{0} /\left(c_{ \pm} \cdot y_{ \pm}\right)^{2} \\
c=c_{0}+c_{ \pm} \\
y_{ \pm}=\varphi\left(c_{ \pm} ; R\right)
\end{gathered}
$$

where $c_{ \pm}, c_{0}$ and $c$ are equilibrium concentration of ions, ionic pairs and stoichiometric concentration of electrolyte respectively, $\Lambda_{0}$ is the limiting molar electrical conductivity, $R$ is the closest approach parameter, $K_{A}$ is the ionic association constant, $f$ and $\varphi$ are theoretical analytical concentration dependencies of $\Lambda$ and $y_{ \pm}$respectively.

Solving the overfilled system of equations $X\left(\Lambda_{0}, K_{A}, R\right)$ comes down to minimization of the sum of squared deviations of experimental electrical conductance $\left(\Lambda^{\exp }\right)$ from respective theoretical values $\left(\Lambda^{\text {theor }}\right)$ :

$$
Q=\sum_{j=1}^{k}\left[\Lambda_{j}^{e x p}-\Lambda_{j}^{\text {theor }}\left(c_{j} ; X\right)\right]^{2} \Rightarrow \min
$$

The Debye-Hückel equation was used for the concentration function of activity coefficients:

$$
\ln y_{ \pm}=-\frac{1}{2} \frac{\beta \kappa_{D}}{\left(1+\kappa_{D} R\right)}
$$

The Pethybridge modification [18] of Lee-Wheaton equation [19-21] was used for the concentration dependence of electrical conductance of diluted solutions:

$$
\begin{aligned}
& \Lambda=\alpha\left\{\Lambda_{0}\left[1+C_{1} \cdot\left(\beta \kappa_{D}\right)+C_{2} \cdot\left(\beta \kappa_{D}\right)^{2}+C_{3} \cdot\left(\beta \kappa_{D}\right)^{3}\right]-\right. \\
& \left.-\frac{\rho \kappa_{D}}{1+\kappa_{D} R}\left[1+C_{4} \cdot\left(\beta \kappa_{D}\right)+C_{5} \cdot\left(\beta \kappa_{D}\right)^{2}+\frac{\kappa_{D} R}{12}\right]\right\}
\end{aligned}
$$

where $\beta=e^{2} /\left(4 \pi \varepsilon \varepsilon_{0} k_{B} T\right), \quad \kappa_{D}^{2}=2 N_{A} e^{2} c / 1000 \varepsilon_{r} \varepsilon_{0} k_{B} T, \rho=F e / 299.7925 \cdot 3 \pi \eta, e$ is the elementary charge, $\varepsilon$ and $\eta$ are dielectric permittivity and viscosity of a pure solvent respectively, $\varepsilon_{0}$ is the vacuum permittivity, $F$ and $N_{A}$ are Faraday's and Avogadro's constants respectively, $k_{B}$ is the Boltzmann constant, $T$ is the temperature, $R$ is the closest approach parameter, $c$ is the electrolyte concentration, $C_{1}-C_{5}$ are terms that characterize electrophoretic and relaxation effects [18].

All required density $\left(d_{0}, \mathrm{~g} \mathrm{~cm}^{-3}\right)$, viscosity $(\eta, \mathrm{mPa} \mathrm{s})$ and dielectric permittivity $(\varepsilon)$ values of pure acetonitrile were calculated using equations (10-12) [22]

$$
\begin{gathered}
1 / d_{0}=1.24446+1.6458 \cdot 10^{-3}(T-273.15)+2.92 \cdot 10^{-6}(T-273.15)^{2} \\
\ln \eta=-3.5164+620 \cdot T^{-1}+32500 \cdot T^{-2} \\
\varepsilon=-21.06+20230 \cdot T^{-1}-963000 \cdot T^{-2}
\end{gathered}
$$




\section{Results and Discussion}

Processing of experimental conductometric data for solutions of tetraalkylammonium salts in acetonitrile was done with regards to three parameters: limiting molar electrical conductivity $\left(\Lambda_{0}\right)$, logarithm of association constant $\left(\lg K_{A}\right)$ and the closest approach parameter $(R)$. The results are presented in Tables 1 and 2 (option I). Concentration functions of molar electrical conductance of tetraalkylammonium salts in acetonitrile are shown in Figure 1.

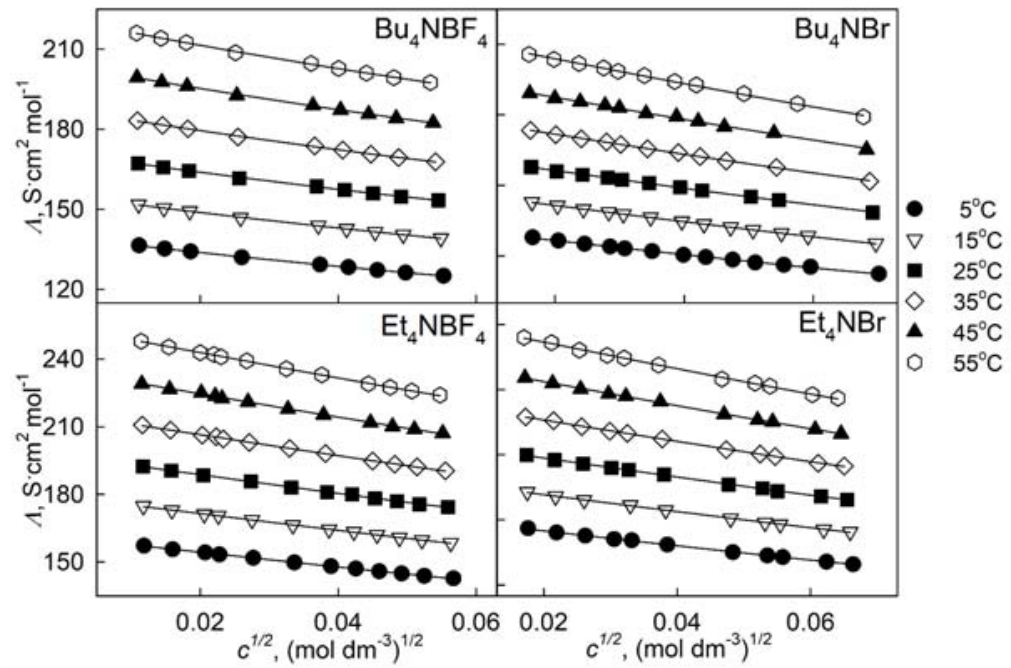

Figure 1. Concentration functions of molar electrical conductivity of tetraalkylammonium salts in acetonitrile at different temperatures. Lines on the figure represent theoretical function of electrical conductance, obtained by the f Lee-Wheaton equation.

Table 1. Results of conductometric data processing for $\mathrm{Bu}_{4} \mathrm{NBF}_{4}$ and $\mathrm{Bu}_{4} \mathrm{NBr}$ in acetonitrile. $\sigma_{\Lambda}$ is a dispersion of approximation.

\begin{tabular}{|c|c|c|c|c|c|}
\hline$t,{ }^{\circ} \mathrm{C}$ & Option & $\Lambda_{0}, \mathrm{~S} \cdot \mathrm{cm}^{2} \cdot \mathrm{mol}^{-1}$ & $\lg \mathrm{K}_{A}$ & $R, \mathrm{~nm}$ & $\sigma_{\Lambda}, \mathrm{S} \cdot \mathrm{cm}^{2} \cdot \mathrm{mol}^{-1}$ \\
\hline \multicolumn{6}{|c|}{$\mathrm{Bu}_{4} \mathrm{NBF}_{4}$} \\
\hline \multirow{2}{*}{5} & $\mathrm{I}$ & $139.65 \pm 0.08$ & $0.3 \pm 0.4$ & $0.3 \pm 0.2$ & 0.095 \\
\hline & II & $139.57 \pm 0.06$ & $0.76 \pm 0.03$ & 0.726 & 0.097 \\
\hline \multirow{2}{*}{15} & $\mathrm{I}$ & $155.3 \pm 0.1$ & $0.4 \pm 0.5$ & $0.4 \pm 0.3$ & 0.13 \\
\hline & II & $155.26 \pm 0.08$ & $\mathbf{0 . 7 7} \pm \mathbf{0 . 0 3}$ & 0.726 & 0.13 \\
\hline \multirow{2}{*}{25} & I & $171.1 \pm 0.2$ & $0.7 \pm 0.6$ & $0.6 \pm 0.7$ & 0.18 \\
\hline & II & $171.1 \pm 0.1$ & $0.75 \pm 0.04$ & 0.726 & 0.16 \\
\hline \multirow{2}{*}{35} & $\mathrm{I}$ & $187.4 \pm 0.2$ & $0.7 \pm 0.5$ & $0.6 \pm 0.6$ & 0.20 \\
\hline & II & $187.4 \pm 0.1$ & $0.80 \pm 0.04$ & 0.726 & 0.18 \\
\hline \multirow{2}{*}{45} & I & $204.1 \pm 0.2$ & $0.7 \pm 0.5$ & $0.5 \pm 0.5$ & 0.21 \\
\hline & II & $204.0 \pm 0.1$ & $0.84 \pm 0.04$ & 0.726 & 0.20 \\
\hline \multirow{2}{*}{55} & $\mathrm{I}$ & $221.1 \pm 0.2$ & $0.8 \pm 0.5$ & $0.6 \pm 0.7$ & 0.25 \\
\hline & II & $221.1 \pm 0.1$ & $0.88 \pm 0.04$ & 0.726 & 0.24 \\
\hline \multicolumn{6}{|c|}{$\mathrm{Bu}_{4} \mathrm{NBr}$} \\
\hline \multirow{2}{*}{5} & $\mathrm{I}$ & $131.5 \pm 0.2$ & $1.54 \pm 0.02$ & $6.53 \pm 0.02$ & 0.24 \\
\hline & II & $132.55 \pm 0.09$ & $1.18 \pm 0.02$ & 0.690 & 0.16 \\
\hline \multirow{2}{*}{15} & $\mathrm{I}$ & $148.42 \pm 0.05$ & $1.17 \pm 0.01$ & $0.4 \pm 0.6$ & 0.06 \\
\hline & II & $148.27 \pm 0.05$ & $1.222 \pm 0.006$ & 0.690 & 0.08 \\
\hline \multirow{2}{*}{25} & I & $163.5 \pm 0.1$ & $1.35 \pm 0.04$ & $1.7 \pm 0.4$ & 0.12 \\
\hline & II & $163.9 \pm 0.1$ & $1.20 \pm 0.01$ & 0.690 & 0.16 \\
\hline \multirow{2}{*}{35} & I & $179.9 \pm 0.02$ & $1.36 \pm 0.05$ & $1.4 \pm 0.5$ & 0.18 \\
\hline & II & $180.2 \pm 0.1$ & $1.25 \pm 0.01$ & 0.690 & 0.20 \\
\hline \multirow{2}{*}{45} & I & $196.1 \pm 0.3$ & $1.46 \pm .0 .04$ & $2.6 \pm 0.7$ & 0.30 \\
\hline & II & $196.8 \pm 0.2$ & $1.26 \pm 0.02$ & 0.690 & 0.40 \\
\hline \multirow{2}{*}{55} & I & $213.3 \pm 0.2$ & $1.49 \pm 0.02$ & $2.8 \pm 0.4$ & 0.16 \\
\hline & II & $214.2 \pm 0.2$ & $1.31 \pm 0.02$ & 0.690 & 0.35 \\
\hline
\end{tabular}


Analysis of obtained results (Tables 1,2 - option I) had shown that the closest approach parameter is the least sensible parameter, compared to the limiting molar electrical conductivity and the logarithm of association constant. Values of $R$ were almost independent from the temperature and ranged between $0.3-2.8 \mathrm{~nm}$ for all studied acetonitrile solutions. This is why, we chose the closest approach parameter as a sum of cation and anion radii $\left(r\left(\mathrm{Bu}_{4} \mathrm{~N}^{+}\right)=0.494 \mathrm{~nm}, r\left(\mathrm{Et}_{4} \mathrm{~N}^{+}\right)=0.400 \mathrm{~nm}, r\left(\mathrm{BF}_{4}^{-}\right)=0.232 \mathrm{~nm}\right.$, $\left.r\left(\mathrm{Br}^{-}\right)=0.196 \mathrm{~nm}[22]\right)$ and to process conductometric data once again, considering the limiting molar electrical conductivity $\left(\Lambda_{0}\right)$ and the logarithm of association constant $\left(\lg K_{A}\right)$ only as optimized parameters. Obtained data using this approach is shown in Tables 1 and 2 (option II).

It is worth mentioning that obtained values (Table 1,2) of limiting molar electrical conductivities and respective association constants for $\mathrm{Et}_{4} \mathrm{NBF}_{4}, \mathrm{Bu}_{4} \mathrm{NBF}_{4}, \mathrm{Bu}_{4} \mathrm{NBr}$ in acetonitrile are in good agreement with the data, previously obtained in our laboratory [23-25].

Table 2. Results of conductometric data processing for $\mathrm{Et}_{4} \mathrm{NBF}_{4}$ and $\mathrm{Et}_{4} \mathrm{NBr}$ in acetonitrile. $\sigma_{\Lambda}$ is a dispersion of approximation.

\begin{tabular}{cccccc}
\hline$t,{ }^{\circ} \mathrm{C}$ & Option & $\Lambda_{0}, \mathrm{~S} \cdot \mathrm{cm}^{2} \cdot \mathrm{mol}^{-1}$ & $\mathrm{gSK}_{A}$ & $R, \mathrm{~nm}$ & $\sigma_{\Lambda}, \mathrm{S} \cdot \mathrm{cm}^{2} \cdot \mathrm{mol}^{-1}$ \\
\hline & & & $\mathrm{Et}_{4} \mathrm{NBF}_{4}$ & \\
\multirow{2}{*}{5} & I & $160.99 \pm 0.06$ & $1.03 \pm 0.05$ & $0.4 \pm 0.01$ & 0.07 \\
& II & $\mathbf{1 6 0 . 9 2} \pm \mathbf{0 . 0 4}$ & $\mathbf{1 . 1 1 1} \pm \mathbf{0 . 0 0 8}$ & $\mathbf{0 . 6 3 2}$ & $\mathbf{0 . 0 7}$ \\
15 & I & $178.9 \pm 0.1$ & $1.1 \pm 0.1$ & $0.5 \pm 0.3$ & 0.12 \\
& II & $\mathbf{1 7 8 . 8 9} \pm \mathbf{0 . 0 7}$ & $\mathbf{1 . 1 4} \pm \mathbf{0 . 0 1}$ & $\mathbf{0 . 6 3 2}$ & $\mathbf{0 . 1 2}$ \\
25 & I & $197.1 \pm 0.2$ & $1.1 \pm 0.1$ & $0.4 \pm 0.4$ & 0.22 \\
& II & $\mathbf{1 9 7 . 0} \pm \mathbf{0 . 1}$ & $\mathbf{1 . 1 5} \pm \mathbf{0 . 0 2}$ & $\mathbf{0 . 6 3 2}$ & $\mathbf{0 . 2 1}$ \\
35 & I & $215.8 \pm 0.2$ & $1.10 \pm 0.06$ & $0.3 \pm 0.2$ & 0.18 \\
& II & $\mathbf{2 1 5 . 7 \pm 0 . 1}$ & $\mathbf{1 . 1 9} \pm \mathbf{0 . 0 1}$ & $\mathbf{0 . 6 3 2}$ & $\mathbf{0 . 1 8}$ \\
45 & I & $234.9 \pm 0.2$ & $1.12 \pm 0.06$ & $0.3 \pm 0.2$ & 0.27 \\
& II & $\mathbf{2 3 4 . 8} \pm \mathbf{0 . 1}$ & $\mathbf{1 . 2 2} \pm \mathbf{0 . 0 2}$ & $\mathbf{0 . 6 3 2}$ & $\mathbf{0 . 2 7}$ \\
55 & I & $254.2 \pm 0.2$ & $1.14 \pm 0.05$ & $0.3 \pm 0.2$ & 0.19 \\
& II & $\mathbf{2 5 4 . 0} \pm \mathbf{0 . 1}$ & $\mathbf{1 . 2 2} \pm \mathbf{0 . 0 1}$ & $\mathbf{0 . 6 3 2}$ & $\mathbf{0 . 1 9}$ \\
\hline & & & & \\
\hline \multirow{2}{*}{5} & I & $151.6 \pm 0.1$ & $1.24 \pm 0.02$ & $0.5 \pm 0.1$ & 0.17 \\
& II & $\mathbf{1 5 1 . 5 5} \pm \mathbf{0 . 0 9}$ & $\mathbf{1 . 2 4 7} \pm \mathbf{0 . 0 0 8}$ & $\mathbf{0 . 5 9 6}$ & $\mathbf{0 . 1 6}$ \\
15 & I & $169.2 \pm 0.2$ & $1.26 \pm 0.01$ & $0.5 \pm 0.1$ & 0.18 \\
& II & $\mathbf{1 6 9 . 1} \pm \mathbf{0 . 1}$ & $\mathbf{1 . 2 7 0} \pm \mathbf{0 . 0 0 8}$ & $\mathbf{0 . 5 9 6}$ & $\mathbf{0 . 1 8}$ \\
25 & I & $186.9 \pm 0.2$ & $1.29 \pm 0.01$ & $0.6 \pm 0.01$ & 0.18 \\
& II & $\mathbf{1 8 6 . 8 8} \pm \mathbf{0 . 0 9}$ & $\mathbf{1 . 2 9 1} \pm \mathbf{0 . 0 0 7}$ & $\mathbf{0 . 5 9 6}$ & $\mathbf{0 . 1 7}$ \\
35 & I & $205.5 \pm 0.2$ & $1.29 \pm 0.01$ & $0.4 \pm 0.1$ & 0.23 \\
& II & $\mathbf{2 0 5 . 3 \pm 0 . 1}$ & $\mathbf{1 . 3 2} \pm \mathbf{0 . 0 1}$ & $\mathbf{0 . 5 9 6}$ & $\mathbf{0 . 2 3}$ \\
45 & I & $224.0 \pm 0.2$ & $1.37 \pm 0.02$ & $0.7 \pm 0.2$ & 0.25 \\
& II & $\mathbf{2 2 4 . 1} \pm \mathbf{0 . 1}$ & $\mathbf{1 . 3 6 5} \pm \mathbf{0 . 0 0 7}$ & $\mathbf{0 . 5 9 6}$ & $\mathbf{0 . 2 4}$ \\
55 & I & $243.5 \pm 0.3$ & $1.37 \pm 0.01$ & $0.5 \pm 0.1$ & 0.37 \\
& II & $\mathbf{2 4 3 . 3} \pm \mathbf{0 . 2}$ & $\mathbf{1 . 3 8} \pm \mathbf{0 . 0 1}$ & $\mathbf{0 . 5 9 6}$ & $\mathbf{0 . 3 6}$ \\
\hline
\end{tabular}

Limiting ionic conductance and dynamic of ionic solvation

Temperature dependences of limiting molar conductivity of $\mathrm{Et}_{4} \mathrm{NBr}, \mathrm{Et}_{4} \mathrm{NBF}_{4}, \mathrm{Bu}_{4} \mathrm{NBr}, \mathrm{Bu}_{4} \mathrm{NBF}_{4}$ in acetonitrile are shown in Figure 2. The increase in the limiting molar conductance of electrolyte with the increase of the temperature can be explained by the decrease of the solvent viscosity.

Limiting molar conductivities of tetraalkylammonium tetrafluoroborates are greater than limiting molar conductance of tetraalkylammonium bromides for both electrolytes at all temperatures studied. This evidence is a consequence of the fact that bromide ion has smaller radius and greater surface charge that increases solvation interactions, and, as a result, decreases the mobility of bromide ion in contrast to poorly solvated tetrafluoroborate anion.

Comparing limiting molar conductivities of electrolytes with the same anion, electrolyte with a smaller cation $\left(\mathrm{Et}_{4} \mathrm{NX}\right)$ has a greater value of molar conductance. 


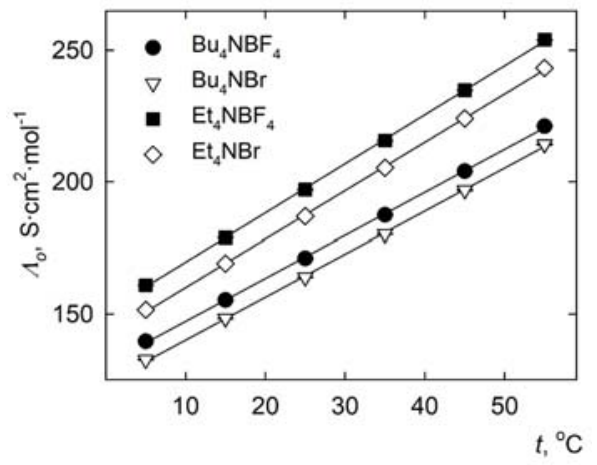

Figure 2. Temperature dependence of limiting molar conductivity of tetraalkylammonium salts in acetonitrile.

In order to elucidate the influence of ion on the microscopic structure of the closes molecular environment, the values of limiting ionic conductivities have been studied. The splitting of total limiting molar conductivity on the ionic constituents was done by the following scheme:

$$
\mathrm{Bu}_{4} \mathrm{NBPh}_{4}\left\{\begin{array}{l}
\rightarrow \mathrm{BPh}_{4}^{-} \\
\rightarrow \mathrm{Bu}_{4} \mathrm{~N}^{+} \stackrel{\mathrm{Bu}_{4} \mathrm{NBr}}{\longrightarrow} \mathrm{Br}^{-} \stackrel{\mathrm{Et}_{4} \mathrm{NBr}_{4}}{\longrightarrow} \mathrm{Et}_{4} \mathrm{~N}^{+} \\
\stackrel{\mathrm{Bu}_{4} \mathrm{NBF}_{4}}{\longrightarrow} \mathrm{BF}_{4}^{-} \stackrel{\mathrm{Et}_{4} \mathrm{NBF}_{4}}{\longrightarrow} \uparrow
\end{array}\right.
$$

Available literature values of Walden's product for $\mathrm{Bu}_{4} \mathrm{~N}^{+}$and $\mathrm{BPh}_{4}{ }^{-}$ions in acetonitrile at $25^{\circ} \mathrm{C}$ [26] were used to calculate the transference number of tetrabutylammonium cation (14):

$$
t^{+}\left(\mathrm{Bu}_{4} \mathrm{NBPh} 4\right)=\frac{\lambda_{0}^{+} \cdot \eta}{\lambda_{0}^{+} \cdot \eta+\lambda_{0}^{-} \cdot \eta}=\frac{0.2122}{0.2122+0.1993}=0.5157
$$

Values of $\lambda_{0}^{+}\left(\mathrm{Bu}_{4} \mathrm{~N}^{+}\right)$at other temperatures $\left(5,15,35,45\right.$ and $\left.55{ }^{\circ} \mathrm{C}\right)$ were calculated by using available in the literature data on the limiting molar conductivities of $\mathrm{Bu}_{4} \mathrm{NBPh}_{4}$ solutions in acetonitrile [27]. The calculation was done using equations $(15,16)$ assuming independence of transference number $t^{+}\left(\mathrm{Bu}_{4} \mathrm{NBPh}_{4}\right)$ on temperature in non-aqueous solvents [28].

$$
\begin{aligned}
\lambda_{0}^{i} & =t^{i} \cdot \Lambda_{0}, \\
\Lambda_{0} & =\lambda_{0}^{+}+\lambda_{0}^{-}
\end{aligned}
$$

On the next step according to the scheme (13), we have calculated limiting ionic conductivities of for all other ions (Table 3 ) by using our own experimental conductometric data of total limiting molar conductivities (Tables 1,2).

In this work two values of limiting ionic conductance of $\mathrm{Et}_{4} \mathrm{~N}^{+}$were obtained: derived from limit-

\begin{tabular}{|c|c|c|c|c|c|c|c|}
\hline \multirow{2}{*}{$\mathrm{t},{ }^{\circ} \mathrm{C}$} & \multirow{2}{*}{$\mathrm{Bu}_{4} \mathrm{~N}^{+}$} & \multirow{2}{*}{$\mathrm{BPh}_{4-}$} & \multirow{2}{*}{$\mathrm{BF}_{4}^{-}$} & \multirow{2}{*}{$\mathrm{Br}^{-}$} & \multicolumn{3}{|c|}{$\mathrm{Et}_{4} \mathrm{~N}^{+}$} \\
\hline & & & & & $\left(\mathrm{Br}^{-}\right)$ & $\left(\mathrm{BF}_{4}^{-}\right)$ & average \\
\hline \multirow{3}{*}{5} & 50.00 & 46.95 & \multirow{3}{*}{89.57} & & \multirow{3}{*}{69.00} & \multirow{3}{*}{71.35} & 70.18 \\
\hline & 49.82 [27] & 46.91 [27] & & $\begin{array}{c}82.55 \\
8180.27\end{array}$ & & & 69.61 [27] \\
\hline & 49.97 [29] & 46.79 [29] & & & & & 69.51 [29] \\
\hline \multirow{3}{*}{15} & 55.83 & 52.43 & \multirow{3}{*}{99.43} & & \multirow{3}{*}{76.66} & \multirow{3}{*}{79.46} & 78.06 \\
\hline & $55.71[27]$ & 52.29 [27] & & $\begin{array}{c}92.44 \\
0076\end{array}$ & & & $77.02[27]$ \\
\hline & 55.70 [29] & 52.31 [29] & & & & & 77.25 [29] \\
\hline \multirow{3}{*}{25} & 61.90 & 58.13 & \multirow{3}{*}{$\begin{array}{c}109.20 \\
96.8[27]\end{array}$} & 102.00 & \multirow{3}{*}{84.88} & \multirow{3}{*}{87.80} & 86.34 \\
\hline & $61.30-62.3$ & $57.7-58.14$ & & $100.27-101.6$ & & & $83.7-85.9$ \\
\hline & {$[16,27,29-30]$} & {$[16,27,29-30]$} & & {$[16,27,29-30]$} & & & {$[16,27,29-30]$} \\
\hline \multirow{2}{*}{35} & 68.15 & 64.00 & \multirow{2}{*}{119.25} & 112.05 & \multirow{2}{*}{93.25} & \multirow{2}{*}{96.45} & 94.85 \\
\hline & 66.98 [27] & 64.73 [27] & & 112.07 [27] & & & 91.74 [27] \\
\hline \multirow{2}{*}{45} & 74.72 & 70.17 & \multirow{2}{*}{129.28} & 122.08 & \multirow{2}{*}{102.02} & \multirow{2}{*}{105.52} & 103.77 \\
\hline & 72.87 [27] & 71.94 [27] & & 121.70 [27] & & & 100.11 [27] \\
\hline 55 & 79.07 & 74.25 & 142.03 & 135.13 & 108.17 & 111.97 & 110.07 \\
\hline
\end{tabular}
ing molar conductivity of $\mathrm{Et}_{4} \mathrm{NBF}_{4}$ and $\mathrm{Bu}_{4} \mathrm{NBF}_{4}$ (Table 1,2). The average values of limiting ionic conductivity of $\mathrm{Et}_{4} \mathrm{~N}^{+}$(the last column of the Table 3) was used for further interpretation.

Table 3. Values of limiting molar electrical conductivities of ions in acetonitrile $\left(\lambda_{0}, \mathrm{~S} \cdot \mathrm{cm}^{2} \cdot \mathrm{mol}^{-1}\right)$ 
Comparison of $\lambda_{0}^{\mathrm{i}}$ given in the Table 3 indicate a good agreement of obtained ionic conductivities with the data available in literature. Insignificant deviations might be caused by the different assumptions taken for splitting total molar conductivity on ionic constituents.

Immersion of an ion into the solvent medium leads to the change in the structure of the latter. The most significant deviations occur in the closest environment of an ion. The presence of an ion not only changes the mutual arrangement of the solvent molecules but also their kinetic parameters. The influence of the ion on the dynamic structure of the closest molecular environment can be evaluated using the approach, proposed by Kalugin with co-authors [31-34], which is a further development of the Samoilov's kinetic solvation theory for non-aqueous solutions.

Joint consideration of Hubbard-Onsager dielectric friction theory and Wolynes molecular theory allows to express Hubbard-Onsager's radius $\left(R_{H O}\right)$ in the following way [31-34]:

$$
R_{H O}=\left\{\frac{\left(z e \mu_{v}\right)^{2}}{12\left(4 \pi \varepsilon_{0} k_{B} T\right)^{2}} \frac{\left(\varepsilon_{\infty}+2\right)^{2}}{\varepsilon\left(2 \varepsilon+\varepsilon_{\infty}\right)}\left(g_{K} \gamma_{D}\right)^{0}\right\}^{1 / 4}
$$

where $z e$ is the ion charge, $\mu_{V}$ is the dipole momentum of the solvent molecule in the vacuum, $\varepsilon, \varepsilon_{\infty}$ are static and infinite frequency dielectric permittivity of the solvent molecule respectively, $g_{K}$ and $\gamma_{D}$ are Kirkwood and Debye structure-sensitive factors respectively, where zero-index at $\left(g_{K} \gamma_{D}\right)^{0}$ refers to the pure solvent. In the expression $(17)\left(g_{K} \gamma_{D}\right)^{0}$ product characterizes dynamic structure of the pure solvent. When an ion is immersed in a molecular environment, $g_{K} \gamma_{D}$ must undergo significant change, which in its turn will lead to the change of theoretical Hubbard-Onsager radius [35]. Combining the deviation of the effective Hubbard-Onsager radius with the change of the $g_{K} \gamma_{D}$ product under the influence of the ion, expression (18) was derived

$$
R_{H O}^{e f}=\left\{\frac{\left(z e \mu_{v}\right)^{2}}{12\left(4 \pi \varepsilon_{0} k_{B} T\right)^{2}} \frac{\left(\varepsilon_{\infty}+2\right)^{2}}{\varepsilon\left(2 \varepsilon+\varepsilon_{\infty}\right)}\left(g_{K} \gamma_{D}\right)^{e f}\right\}^{1 / 4}
$$

$\left(g_{K} \gamma_{D}\right)^{e f}$ value can be obtained from the experimental values of ionic conductivities by equations given in [31].

Therefore, the ratio of $\left(g_{K} \gamma_{D}\right){ }^{e f}$ to the corresponding value for the pure solvent can be used as a measure of the ion's influence on the dynamic structure of the closest molecular environment [31-34]:

$$
\theta=\left(g_{K} \gamma_{D}\right)^{e f} /\left(g_{K} \gamma_{D}\right)^{0}
$$

Such an approach allows to obtain quantitative parameter $(\theta)$ for the closest solvation based on the experimental data of ionic conductivities and physicochemical properties of the pure solvent.

In the framework of the abovementioned approach, we have calculated the values of structuredynamic parameter $\theta$ for the studied ions in acetonitrile using our own experimental values of ionic conductivities in the temperature range of $5-55^{\circ} \mathrm{C}$ (Figure 3 ).

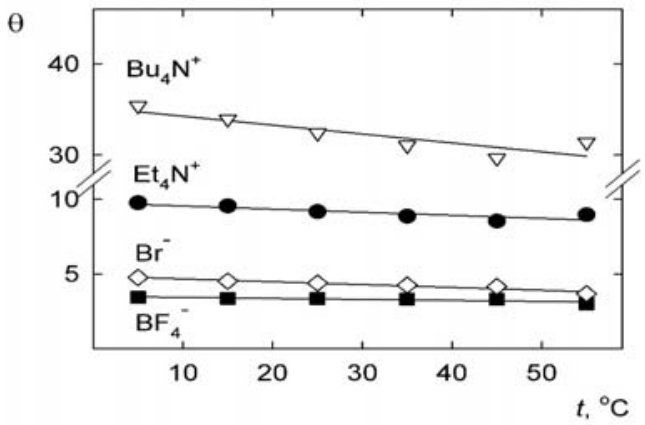

Figure 3. Temperature dependence of structure-dynamic parameter $\theta$ for $\mathrm{Bu}_{4} \mathrm{~N}^{+}, \mathrm{Et}_{4} \mathrm{~N}^{+}, \mathrm{Br}^{-}$and $\mathrm{BF}_{4}^{-}$in acetonitrile.

In accordance with the Samoilov's kinetic solvation theory [36], ionic solvation parameter $\theta$ is interpreted as a measure of the ion's influence on the dynamic structure of the solvent. Values of $\theta>1$ correspond to the "structure-making" influence of the ion on the solvent in the closest environment. In the opposite case, values of $\theta<1$ indicate that ion acts as a "structure-breaker". 
Parameter $\theta$ for all investigated ions is positive that corresponds to the structure-making effect of the ion, also referred to as positive solvation. Cations facilitate the increase in vibrational stability of the solvent's structure in the greater extent than anions due to the specific interaction with the closest molecules. Elongation of the alkyl chain from $\mathrm{Et}_{4} \mathrm{~N}^{+}$to $\mathrm{Bu}_{4} \mathrm{~N}^{+}$is accompanied by the significant increase of the $\theta$ parameter, which is an evidence of the dynamic structuring of the solvent molecules around tetrabutylammonium cation and of the amplification of solvophobic solvation of $\mathrm{Bu}_{4} \mathrm{~N}^{+}$cation compared to the $\mathrm{Et}_{4} \mathrm{~N}^{+}$.

$\mathrm{BF}_{4}^{-}$and $\mathrm{Br}^{-}$anions strengthen spatio-temporal correlations between solvent molecules in their solvation shells to the less extent when compared to cations. This is characteristic for anions in aprotic solvents due to the absence of specific interactions between solvent molecules and anions.

With the increase of the temperature, the magnitude of the $\theta$ parameter decreases, which is explained by the increase of the relative mobility of particles in the solvent layer.

Obtained results for $\theta$ parameter allow one to formulate the following recommendations regarding the electrolyte choice (both cation and anion) for SCs. Evidently, the less pronounced the effects of positive (solvophilic or solvophobic) solvation are, the higher the limiting molar electrical conductivity of the ion is. Considering values of structure-dynamic parameter $\theta$, optimal electrolytes for SCs should contain polyatomic ions whose diameter range between 0.2 to $0.4 \mathrm{~nm}$.

\section{Ionic association of tetraalkylammonium salts in acetonitrile}

Electrolytes, studied in this work, just like overwhelming number of other tetraalkylammonium salts in acetonitrile [37], are weakly associated electrolytes (respective association constants do not exceed $20 \mathrm{dm}^{3} \mathrm{~mol}^{-1}$ at $25^{\circ} \mathrm{C}$ ).

Statistical theory of ionic association states that association constant can be represented as a function of pair potential of interionic interaction $U_{ \pm}(r)$ [38]:

$$
K_{A}=\frac{4 \pi N_{A}}{1000} \int_{0}^{\infty} r^{2} \omega(r) \exp \left(-\frac{U_{ \pm}(r)}{k_{B} T}\right) d r
$$

where $\omega(r)$ is a weight function of the paired state.

Equation (20) allows one to evaluate the value of association constant in terms of concept of simple electrostatic interactions between ions. Here we used Ebeling model to calculate Coulomb association constants [39]:

$$
K_{A}^{\text {Coul }}(r)=\frac{4 \pi N_{A}}{1000} \int_{x}^{\infty} r^{2} w(r) \exp \left(-\frac{U_{ \pm}^{\text {Coul }}(r)}{k_{B} T}\right) d r
$$

Coulomb association constants calculated by equation (21) as a function of temperature and experimental association constants of studied tetraalkylammonium salts in acetonitrile are shown on Figure 4.

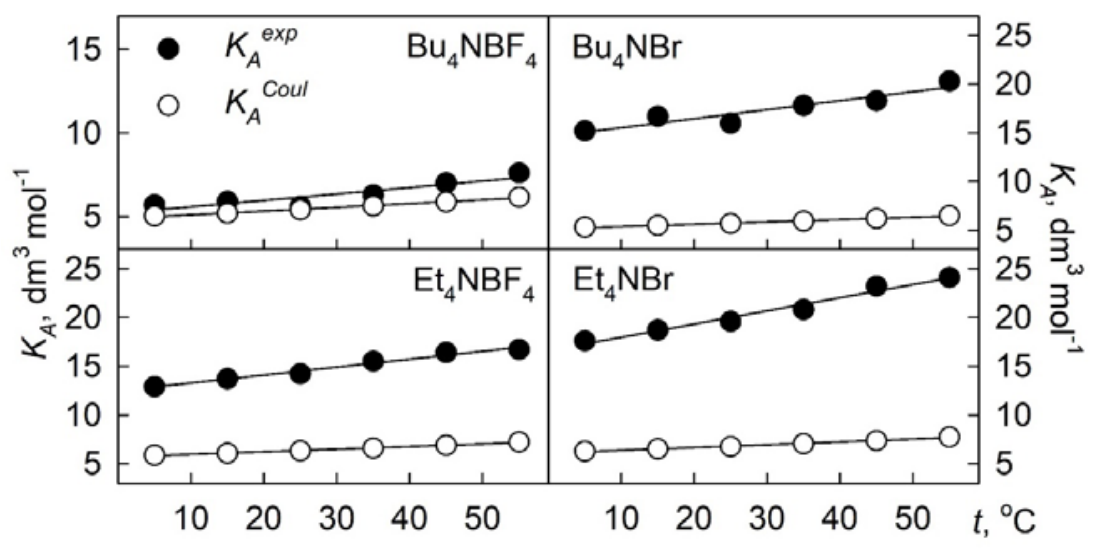

Figure 4. Experimental values of association constants and respective Coulomb contribution for studied tetraalkylammonium salts in acetonitrile. 
Figure 4 clearly demonstrates that only association of tetrabutylammonium tetrafluoroborate is almost completely caused by the Coulomb interaction. For all other tetraalkylammonium salts in acetonitrile, solvation effects contribute to the association to the greater extent than Coulomb attraction. Solvation effects can be evaluated having reviewed the structure of paired interionic potential in more detail.

The adequate representation of the ion-ion interaction potential is a central point in the statistical description of electrolyte solutions at the McMillan-Mayer level [40]. Definite progress has been achieved in describing the long-range electrostatic interactions. Taking into account the nonelectrostatic ion-ion interactions, which are manifested at short distances primarily as a consequence of the discrete structure of the solvent and strong ion-molecule interactions, is a more difficult task. One of the simplest ways used to describe non-electrostatic short-range ion-ion interactions is to add the square-mound potential $d_{ \pm}=$const with a radius of action from $a$ to $R^{\prime}$ to the electrostatic potential $U^{\text {Coul }}[40]$ :

$$
U_{ \pm}(r)=\left\{\begin{array}{lc}
\infty, & r<a, \\
U^{\text {Coul }}(r)+d_{ \pm}, & a<r<R^{\prime}, \\
U^{\text {Coul }}(r), & r>R^{\prime} .
\end{array}\right\}
$$

Here, the hard-core diameter $a=r_{i}+r_{j}$ is the sum of the ion crystallographic or structural radii. The distance $R^{\prime}$ is calculated as $R^{\prime}=a+n S$, where $S$ is the diameter of a solvent molecule or its functional group. $n S$ is the thickness of the first solvation shell.

Taking into account the expression (22), equation (20) can be expressed as:

$$
K_{A}=\frac{4 \pi N_{A}}{1000}\left\{\exp \left(-\frac{d_{ \pm}}{k_{B} T}\right)\left[K_{A}^{\text {Coul }}(a)-K_{A}^{\text {Coul }}\left(R^{\prime}\right)\right]+K_{A}^{\text {Coul }}\left(R^{\prime}\right)\right\}
$$

This equation allows one to evaluate $d_{ \pm}$values having experimental data on association constants and theoretical estimation for Coulomb association constants, for example by equation (21). The calculated in this way values of non-Coulomb short-range potential $d_{ \pm}$for tetraalkylammonium salts in acetonitrile are shown on Figure 5. The values of the radii of the ions were taken from [41]. The upper boundary of action of the non-electrostatic potential $R^{\prime}$ was determined, as in the original paper by Rasaiah and Friedman [40], from the relation $R^{\prime}=a+S$. The diameter of the AN molecule was calculated from the molar volume of the solvent.

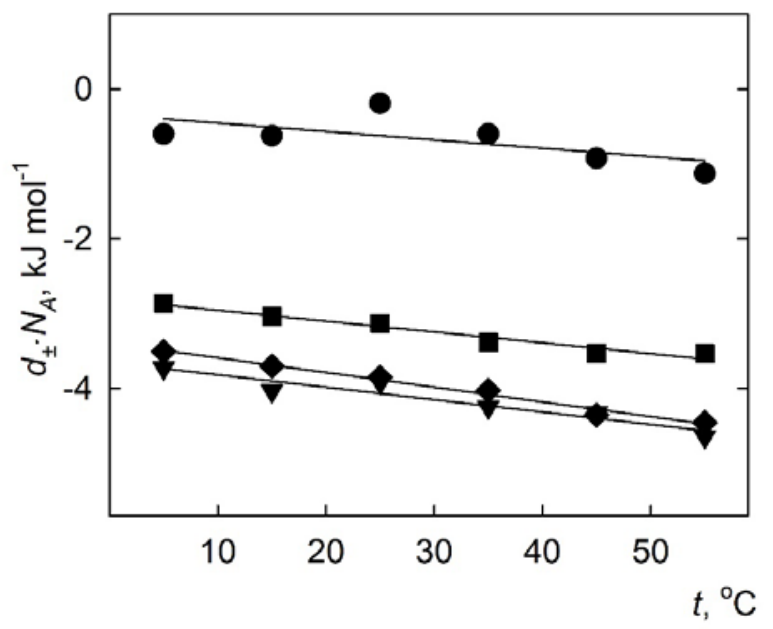

Figure 5. Short-range non-Coulomb potentials $d_{ \pm} \cdot N_{A}$ (in molar scale) for $\mathrm{Bu}_{4} \mathrm{NBF}_{4}(\bullet), \operatorname{Bu} \mathrm{NBr}_{4}(\boldsymbol{\nabla})$, $\mathrm{Et}_{4} \mathrm{NBF}_{4}(\boldsymbol{\square}), \mathrm{Et}_{4} \mathrm{NBr}(\bullet)$ in acetonitrile as a function of temperature.

Negative values of $d_{ \pm} \cdot N_{A}$ product (Figure 5) for all studied tetraalkylammonium salts in acetonitrile testify additional attraction between ions in ionic pair due to solvation effects, which leads the equilibrium $\mathrm{Kt}^{+}+\mathrm{An}^{-} \rightleftarrows\left[\mathrm{Kt}^{+} \mathrm{An}^{-}\right]$to be shifted towards the ionic pair formation. 
It is also worth mentioning that $d_{ \pm} \cdot N_{A}$ value for $\mathrm{Bu}_{4} \mathrm{NBF}_{4}$ tends to 0 and is significantly less by the absolute value, compared to other studied electrolytes. This proves the insignificance of contribution of the solvation effects to the ionic association for tetrabutylammonium tetrafluoroborate.

Desolvation with the increase of the temperature causes the absolute value of $d_{ \pm} \cdot N_{A}$ product to decrease for all studied electrolytes.

Considering proximity of $K_{A}^{\text {Coul }}$ values for all tetraalkylammonium salts in acetonitrile, an increase of experimental values of association constants in sequence $\mathrm{Bu}_{4} \mathrm{NBF}_{4}<\mathrm{Et}_{4} \mathrm{NBF}_{4}<\mathrm{Bu}_{4} \mathrm{NBr}<\mathrm{Et}_{4} \mathrm{NBr}$ is defined by the increase of solvation interactions.

Based on the analysis of obtained experimental data about the association constants of tetraalkylammonium salts, as well as different contributions to these values, the most promising from the practical point of view combination of cation and anion for the SCs electrolyte should provide minimal value of $K_{A}^{\text {Coul }}$ and the absence of negative values of $d_{ \pm} \cdot N_{A}$ product.

\section{Conclusions}

In this study it was found that tetraalkylammonium salts in acetonitrile are weakly associated electrolytes. An increase in ion association constants in the sequence $\mathrm{Bu}_{4} \mathrm{NBF}_{4}<\mathrm{Et}_{4} \mathrm{NBF}_{4}<\mathrm{Bu}_{4} \mathrm{NBr}<\mathrm{Et}_{4} \mathrm{NBr}$ is caused by the increase in the contribution of short-range ion-molecular interactions into interionic attraction in addition to the electrostatic constituent. An increase of the temperature amplifies the ionic association with regards to both electrostatic and short-range constituents.

The highest values of limiting ionic conductivity in acetonitrile were observed for polyatomic ions with the radius ranging from 0.2 to $0.4 \mathrm{~nm}$ that are not inclined to the positive solvophilic or solvophobic solvation. Analysis of structure-dynamic characteristics of ion-molecular interactions in solutions studied had shown that the increase in polyatomic ions radii leads to the decrease of the limiting ionic conductivity due to viscosity constituent and magnification of solvophobic solvation. Influence of the temperature on the limiting ionic conductivity is mainly caused by the change of the solvent's viscosity.

\section{Acknowledgements}

Authors acknowledge the Grant No.0118U002025 of Ministry of Education and Science of Ukraine for the financial support.

\section{Appendix A}

Table A1. Primary experimental data of electrical conductivity of tetraalkylammonium salts in acetonitrile

\begin{tabular}{cccccccc}
\hline \multirow{2}{*}{$\#$} & $\tilde{m} \cdot 10^{4}$ & \multicolumn{6}{c}{$\kappa \cdot 10^{5}, \mathrm{~S} \mathrm{~cm}^{-1}$} \\
\cline { 3 - 7 } & $\mathrm{mol} \mathrm{kg}^{-1}$ & $5^{\circ} \mathrm{C}$ & $15^{\circ} \mathrm{C}$ & $25^{\circ} \mathrm{C}$ & $35^{\circ} \mathrm{C}$ & $45^{\circ} \mathrm{C}$ & $55^{\circ} \mathrm{C}$ \\
\hline & & & & $\mathrm{Bu}_{4} \mathrm{NBF}_{4}$ & & & \\
1 & 1.5634 & 1.7055 & 1.8718 & 2.0331 & 2.1966 & 2.3565 & 2.5164 \\
2 & 2.7671 & 2.9902 & 3.2811 & 3.5651 & 3.8499 & 4.132 & 4.4114 \\
3 & 4.3503 & 4.6626 & 5.1161 & 5.5612 & 6.0067 & 6.4451 & 6.882 \\
4 & 6.1343 & 6.5047 & 7.1453 & 7.7661 & 8.3827 & 9.0004 & 9.6084 \\
5 & 7.7893 & 8.282 & 9.0995 & 9.8932 & 10.682 & 11.466 & 12.238 \\
6 & 8.4956 & 8.954 & 9.8256 & 10.674 & 11.527 & 12.363 & 13.196 \\
7 & 10.18 & 10.734 & 11.787 & 12.805 & 13.821 & 14.83 & 15.83 \\
8 & 12.343 & 12.923 & 14.183 & 15.412 & 16.643 & 17.856 & 19.054 \\
9 & 17.518 & 18.083 & 19.862 & 21.596 & 23.314 & 24.999 & 26.687 \\
10 & 21.585 & 22.114 & 24.258 & 26.379 & 28.474 & 30.523 & 32.582 \\
11 & 26.149 & 26.564 & 29.142 & 31.684 & 34.194 & 36.677 & 39.128 \\
12 & 31.052 & 31.311 & 34.366 & 37.332 & 40.299 & 43.182 & 46.08 \\
13 & 38.28 & 38.244 & 41.966 & 45.619 & 49.224 & 52.764 & 56.281 \\
\hline
\end{tabular}


Continuation of Table A1.

\begin{tabular}{|c|c|c|c|c|c|c|c|}
\hline & \multicolumn{7}{|c|}{$\mathrm{Bu}_{4} \mathrm{NBr}$} \\
\hline 1 & 1.959 & 0.20333 & 0.22461 & 0.24205 & 0.26485 & 0.2832 & 0.30393 \\
\hline 2 & 3.4194 & 0.34967 & 0.38537 & 0.41982 & 0.45494 & 0.48935 & 0.52443 \\
\hline 3 & 5.2692 & 0.53241 & 0.58709 & 0.63903 & 0.69317 & 0.7452 & 0.79955 \\
\hline 4 & 7.5503 & 0.75454 & 0.83225 & 0.9071 & 0.98286 & $1.06 \mathrm{e}-4$ & $1.14 \mathrm{e}-4$ \\
\hline 5 & 9.3915 & 0.93532 & 1.0324 & 1.1257 & 1.2186 & 1.3136 & 1.4077 \\
\hline 6 & 10.185 & 1.0079 & 1.1119 & 1.2136 & 1.315 & 1.4162 & 1.5167 \\
\hline 7 & 11.882 & 1.1683 & 1.289 & 1.4064 & 1.5245 & 1.6422 & 1.7565 \\
\hline 8 & 15.377 & 1.4979 & 1.6518 & 1.803 & 1.9508 & 2.0983 & 2.2521 \\
\hline 9 & 19.94 & 1.9163 & 2.1151 & 2.311 & 2.5055 & 2.6999 & 2.8825 \\
\hline 10 & 23.536 & 2.2442 & 2.4747 & 2.7041 & 2.9274 & 3.1522 & 3.3774 \\
\hline 11 & 28.276 & 2.6725 & 2.9428 & 3.2061 & 3.4741 & 3.7376 & 4.0221 \\
\hline 12 & 32.574 & 3.0462 & 3.3595 & 3.6727 & 3.9934 & 4.3029 & 4.5842 \\
\hline 13 & 38.474 & 3.5678 & 3.9303 & 4.2956 & 4.6468 & 5.0074 & 5.4162 \\
\hline 14 & 44.464 & 4.0932 & 4.4965 & 4.9457 & 5.3597 & 5.7442 & 6.1168 \\
\hline 15 & 61.651 & 5.5303 & 6.0855 & 6.633 & 7.1706 & 7.6962 & 8.2242 \\
\hline 16 & 84.613 & 6.3652 & 6.9969 & 7.7049 & 8.3311 & 9.0111 & 9.6258 \\
\hline \multirow[t]{2}{*}{17} & 94.926 & 6.9463 & 7.6352 & 8.4075 & 9.1062 & 9.7474 & 10.457 \\
\hline & \multicolumn{7}{|c|}{$\mathrm{Et}_{4} \mathrm{NBF}_{4}$} \\
\hline 1 & 1.7677 & 2.2222 & 2.4374 & 2.6474 & 2.8589 & 3.0638 & 3.2698 \\
\hline 2 & 3.2196 & 4.0044 & 4.3898 & 4.768 & 5.1475 & 5.5175 & 5.8869 \\
\hline 3 & 5.3899 & 6.6374 & 7.2713 & 7.895 & 8.5198 & 9.1659 & 9.7483 \\
\hline 4 & 6.52 & 7.9853 & 8.7626 & - & 10.275 & 11.021 & 11.752 \\
\hline 5 & 7.1265 & 8.6922 & 9.5307 & 10.352 & 11.173 & 11.983 & 12.788 \\
\hline 6 & 9.6307 & 11.674 & 12.8 & 13.901 & 14.985 & 16.08 & 17.152 \\
\hline 7 & 14.205 & 16.988 & 18.612 & 20.206 & 21.813 & 2.37 & 24.93 \\
\hline 8 & 19.026 & 22.501 & 24.653 & 26.758 & 28.886 & 30.945 & 33.007 \\
\hline 9 & 22.713 & 26.666 & 29.241 & 31.781 & 34.294 & 36.733 & 39.16 \\
\hline 10 & 26.473 & 30.828 & 33.809 & 36.648 & 39.51 & 42.353 & 45.139 \\
\hline 11 & 30.36 & 35.126 & 38.448 & 41.725 & 44.985 & 48.193 & 51.405 \\
\hline 12 & 34.528 & 39.646 & 43.433 & 47.131 & 50.83 & 54.459 & 58.045 \\
\hline \multirow[t]{2}{*}{13} & 40.299 & 45.926 & 50.285 & 54.612 & 58.809 & 63.054 & 67.221 \\
\hline & \multicolumn{7}{|c|}{$\mathrm{Et}_{4} \mathrm{NBr}$} \\
\hline 1 & 0.22467 & 0.26543 & 0.29314 & 0.31753 & 0.34454 & 0.37152 & 0.3966 \\
\hline 2 & 0.39048 & 0.45555 & 0.50102 & 0.54601 & 0.59086 & 0.63574 & 0.68091 \\
\hline 3 & 0.60217 & 0.6931 & 0.76272 & 0.83122 & 0.90327 & 0.96886 & 1.0388 \\
\hline 4 & 0.86235 & 0.98217 & 1.0811 & 1.1783 & 1.2748 & 1.3701 & 1.4651 \\
\hline 5 & 1.016 & 1.1586 & 1.2744 & 1.3885 & 1.5024 & 1.6116 & 1.727 \\
\hline 6 & 1.1692 & 1.3171 & 1.4418 & 1.5811 & 1.7095 & 1.8377 & 1.9652 \\
\hline 7 & 1.3816 & 1.5504 & 1.7055 & 1.8571 & 2.0093 & 2.1593 & 2.3099 \\
\hline 8 & 1.8607 & 2.0589 & 2.2637 & 2.4708 & 2.6691 & 2.8748 & 3.0656 \\
\hline 9 & 2.365 & 2.6108 & 2.872 & 3.1175 & 3.3797 & 3.6352 & 3.8762 \\
\hline 10 & 2.9285 & 3.1588 & 3.4729 & 3.7825 & 4.0918 & 4.3931 & 4.6843 \\
\hline 11 & 3.5883 & 3.8274 & 4.2029 & 4.5869 & 4.9575 & 5.3103 & 5.6885 \\
\hline 12 & 3.906 & 4.1419 & 4.553 & 4.9534 & 5.3644 & 5.7584 & 6.1533 \\
\hline 13 & 4.3646 & 4.6063 & 5.0654 & 5.5266 & 5.9654 & 6.3929 & 6.8319 \\
\hline 14 & 4.8782 & 5.0903 & 5.5915 & 6.0946 & 6.5803 & 7.0623 & 7.5416 \\
\hline 15 & 5.5218 & 5.7124 & 6.2855 & 6.8356 & 7.3954 & 7.9095 & 8.4709 \\
\hline 16 & 7.498 & 7.5737 & 8.3183 & 9.0379 & 9.7729 & 10.451 & 11.172 \\
\hline 17 & 9.8372 & 9.6683 & 1.0617 & 11.561 & 12.426 & 13.341 & 14.255 \\
\hline
\end{tabular}




\section{References}

1. Kurniawan A., Ong L. K., Kurniawan F., Lin C. X., Soetaredjo F. E., Zhao X. S., Ismadji S. Easy approach to synthesize N/P/K co-doped porous carbon microfibers from cane molasses as a high performance supercapacitor electrode material. RSC Adv. 2014, 4 (66), 34739-34750.

2. Laheäär A., Peikolainen A.-L., Koel M., Jänes A., Lust E. Comparison of carbon aerogel and carbide-derived carbon as electrode materials for non-aqueous supercapacitors with high performance. J. Solid State Electrochem. 2012, 16.

3. Morimoto T., Tsushima M., Suhara M., Hiratsuka K., Sanada Y., Kawasato T. Electric Double- Layer Capacitor using Organic Electrolyte. Mat. Res. Soc. Symp. Proc. 2011, 496 627.

4. Hung K., Masarapu C., Ko T., Wei B. Wide-temperature range operation supercapacitors from nanostructured activated carbon fabric. J. Power Sources 2009, 193 (2), 944-949.

5. Cazorla-Amorós D., Lozano-Castelló D., Morallón E., Bleda-Martínez M. J., Linares-Solano A., Shiraishi S. Measuring cycle efficiency and capacitance of chemically activated carbons in propylene carbonate. Carbon 2010, 48 (5), 1451-1456.

6. Brandt A., Pohlmann S., Varzi A., Balducci A., Passerini S. Ionic liquids in supercapacitors. MRS Bull. 2013, 38 (7), 554-559.

7. Senda A., Matsumoto K., Nohira T., Hagiwara R. Effects of the cationic structures of fluorohydrogenate ionic liquid electrolytes on the electric double layer capacitance. J. Power Sources 2010, 195 (13), 4414-4417.

8. Ue M. Electrochemical Properties of Organic Liquid Electrolytes Based on Quaternary Onium Salts for Electrical Double-Layer Capacitors. J. Electrochem. Soc. 1994, 141 (11), 2989.

9. Wang Y., Song Y., Xia Y. Electrochemical capacitors: mechanism, materials, systems, characterization and applications. Chem. Soc. Rev. 2016, 45 (21), 5925-5950.

10. Das B., Saha N., Hazra D. K. Ionic Association and Conductances of Some Symmetrical Tetraalkylammonium Salts in Methanol, Acetonitrile, and Methanol (1) + Acetonitrile (2) Mixtures at 298.15 K. J. Chem. Eng. Data 2000, 45 (2), 353-357.

11. Anand H., Verma R. Solvation of Some Tetraalkylammonium Salts Investigated Conductometrically and Viscometrically in Binary Mixtures of Acetonitrile + Methanol at 298.15 K. Z. Phys. Chem. 2015, 230.

12. Patil P. P., Tiwari S. Effect of blockage ratio on wake transition for flow past square cylinder. Fluid Dyn. Res. 2008, 40 (11), 753-778.

13. Wypych-Stasiewicz A., Benko J., Vollărovă O., Bald A. Conductance studies of $\mathrm{Et}_{4} \mathrm{NIO}_{4}$, $\mathrm{Et}_{4} \mathrm{NClO}_{4}, \mathrm{Bu}_{4} \mathrm{NI}, \mathrm{Et}_{4} \mathrm{NI}$ and the limiting ionic conductance in water+acetonitrile mixtures at 298.15K. J. Mol. Liq. 2014, 190 54-58.

14. Mysyk R., Gao Q., Raymundo-Piñero E., Béguin F. Microporous carbons finely-tuned by cyclic high-pressure low-temperature oxidation and their use in electrochemical capacitors. Carbon 2012, 50 (9), 3367-3374.

15. Riddick J. A., Bunger W. B., Sakano T. K. Organic solvents: physical properties and methods of purification. Fourth edition. John Wiley and Sons,New York, NY: United States, 1986.

16. Harkness A. C., Daggett Jr H. M. The Electrical Conductivities of some tetra-nalkylammonium salts in acetonitrile. Can. J. Chem. 1965, 43 (5), 1215-1221.

17. Kalugin O. N., Vjunnik I. N. Some issues of conductometric data processing. Existing Electrolyte Options. Russ. J. Gen. Chem. 1989, 59 (7), 1213-1216.

18. Pethybridge A. D., Talbot J., House W. A. Precise Conductance Measurements on Dilute Aqueous Solutions of Sodium and Potassium Hydrogenphosphate and Dihydrogenphosphate. J. Solution Chem. 2006, 35 381-393.

19. Lee W. H., Wheaton R. J. Conductance of symmetrical, unsymmetrical and mixed electrolytes. Part 1.-Relaxation terms. J. Chem. Soc., Faraday Trans. 2 1978, 74 (0), 743-766.

20. Lee W. H., Wheaton R. J. Conductance of symmetrical, unsymmetrical and mixed electrolytes. Part 2.-Hydrodynamic terms and complete conductance equation. J. Chem. Soc., Faraday Trans. 2 1978, 74 (0), 1456-1482. 
21. Lee W. H., Wheaton R. J. Conductance of symmetrical, unsymmetrical and mixed electrolytes. Part 3. - Examination of new model and analysis of data for symmetrical electrolytes. J. Chem. Soc., Faraday Trans. 2 1979, 75 1128-1145.

22. Barthel J., Wachter R., Gores H. J. Temperature Dependence of Conductance of Electrolytes in Nonaqueous Solutions. In Modern Aspects of Electrochemistry: No. 13, Conway, B. E.; Bockris, J. O. M., Eds. Springer US: Boston, MA, 1979; pp 1-79.

23. Lukinova E. V., Kalugin O. N., Novikova A. J. Solutions of $\mathrm{Et}_{4} \mathrm{NBF}_{4}$ in acetonitrile from the standpoint of the quasilattice model: NMR and conductometry studies. Kharkov Univ. Bull. Chem. Ser. 2005, 12(35) (648), 177-180.

24. Lukinova E. V., Ivanova A. A., Kalugin O. N. Concentrated solutions of $\mathrm{Bu}_{4} \mathrm{NBF}_{4}$ in acetonitrile as model electrolytes for supercapacitors: problems and prospects of a theoretical description. Sci. Bull. Chernivtsi Nat. Univ. Chem. 2008, 399-400 116-118.

25. Lukinova E. V., Kalugin O. N. Electrical conductivity of solutions of $\mathrm{Bu}_{4} \mathrm{NBr}$ in acetonitrile in a wide range of concentrations. Kharkov Univ. Bull. Chem. Ser. 2009, 17(40) (870), 178-184.

26. Krumgalz B. Separation of limiting equivalent conductances into ionic contributions in nonaqueous solutions by indirect methods. J. Chem. Soc., Faraday Trans. 1 1983, 79.

27. Safonova L. P., Pasasia, B. K., Kolker, A. M. Electrical conductivity of individual ions and their association in acetonitrile at 233-318 K. Russ. J. Phys. Chem. 1992, 66 (8), 2201-2208.

28. Krumgalz B., Fleisher Z. Comments on Gill's approach to the evaluation of single limiting ionic conductances in organic solvents. J. Chem. Soc., Faraday Trans. 1 1985, 81.

29. Barthel J., Iberl L., Rossmaier J., Gores H. J., Kaukal B. Conductance of 1,1-electrolytes in acetonitrile solutions from $-40^{\circ}$ to $35^{\circ} \mathrm{C}$. J. Solution Chem. 1990, 19 (4), 321-337.

30. Tsierkezos N. G., Philippopoulos A. I. Studies of ion solvation and ion association of n-tetrabutylammonium hexafluorophosphate and n-tetrabutylammonium tetraphenylborate in various solvents. Fluid Phase Equilib. 2009, 277 (1), 20-28.

31. Kalugin O. N., Vjunnik I. N. Limiting ion conductance and dynamic structure of the solvent in electrolyte solution. Zh. Khim. Fiz. (Rus.) 1991, 10 708-714.

32. Kalugin O. N., Vjunnik I. N., Nur-Eddin I. Interparticle interactions in 1-1 electrolyte solutions in dimethylsulfoxide. II. Limiting molar conductance of ions and dynamic structure of solvent. Russ. J. Struct. Chem. 1992, 33 105-114.

33. Lebed A. V., Kalugin O. N., Vjunnik I. N. Properties of 1-1 Electrolytes Solutions in Ethylene Glycol at Temperatures from 5 to $175 \mathrm{oC}$. II. Limiting ion conductances and Ion-Molecular Interactions. J. Chem. Soc., Faraday Trans. 2 1998, 94 (15), 2103-2107.

34. Kalugin O. N. Dynamics of solvated ion in infinitely diluted solution: from phenomenology to microscopic description. Kharkov Univ. Bull. Chem. Ser. 2002, 9 (573), 13-45.

35. Zhang H., Wang J., Chen Y., Wang Z., Wang S. Long-term cycling stability of polyaniline on graphite electrodes used for supercapacitors. Electrochim. Acta 2013, 105 69-74.

36. Samoilov O. Y. Stucture of water solutions of electrolytes and hydration of ions. Nauka, 1957; p 183.

37. Barthel J., Kunz W. Vapor pressure data for non-aqueous electrolyte solutions. Part 5. Tetraalkylammonium salts in acetonitrile. J. Solution Chem. 1988, 17 (5), 399-415.

38. Vjunnik I. N., Kalugin O. N., Gubskiy S. M. Non-Coulombic parameters of interparticle interactions in non-aqueous solutions of 1-1 electrolytes in a wide temperature range. Kharkov Univ. Bull. Chem. Ser. 1993, 377 15-30.

39. Ebeling W. Theorie der Bjerrumschen Ionenassoziation in Elektrolyten. Z. Phys. Chem. 1968, $238(5 / 6), 400-408$.

40. Rasaiah J. C., Friedman H. L. Charged square-well model for ionic solutions. J. Phys. Chem. 1968, $72(9), 3352-3353$.

41. Barthel, J.; Gores, H. J.; Hess, P.; Kniep, R.; Rabenau, A.; Schmeer, G.; Wachter, R., Physical and Inorganic Chemistry. Springer-Verlag Berlin Heidelberg: 1983; Vol. 111, p VII, 196. 
Electrical conductivity, ion-molecular and interionic interactions in solutions of some ...

О.Н. Калугин, Е.В. Лукинова, Д.О. Новиков. Электрическая проводимость, ион-молекулярная ассоциация и межионные взаимодействия в растворах некоторых тетраалкиламмониевых солей в ацетонитриле: влияние иона и температуры.

Харьковский национальный университет имени В.Н. Каразина, химический факультет, кафедра неорганической химии, пл. Свободы, 4, Харьков, 61022, Украина

В работе представлены экспериментальные данные по электрической проводимости растворов $\mathrm{Et}_{4} \mathrm{NBr}$, $\mathrm{Et}_{4} \mathrm{NBF}_{4}, \mathrm{Bu}_{4} \mathrm{NBr}, \mathrm{Bu}_{4} \mathrm{NBF}_{4}$ в ацетонитриле в интервале концентраций $2 \cdot 10^{-4}-1 \cdot 10^{-2}$ моль дм ${ }^{-3}$ при температуpax 5 - $55^{\circ} \mathrm{C}$. Предельные молярные электропроводности и константы ионной ассоциации рассчитаны с использованием уравнения Ли-Уитона для симметричных электролитов. На основании предварительного анализа кондуктометрических данных было установлено, что параметр наибольшего сближения практически не зависит от температуры для всех исследованных ацетонитрильных растворов. Поэтому параметр наибольшего сближения был принят как сумма радиусов катионов и анионов для дальнейшей обработки кондуктометрических данных.

Значения предельных ионных проводимостей $\mathrm{Br}^{-}, \mathrm{BF}_{4}^{-}, \mathrm{Et}_{4} \mathrm{~N}^{+}$та $\mathrm{Bu}_{4} \mathrm{~N}^{+}$, а также структурнодинамического параметра ион-молекулярного взаимодействия, полученные по экспериментальным предельным молярным проводимостям, были интерпретированы в рамках предложенного авторами подхода [Kalugin O. N., Vjunnik I. N. Limiting ion conductance and dynamic structure of the solvent in electrolyte solution. Zh. Khim. Fiz. (Rus.) 1991, 10 708-714]. Установлено что удлинение алкильного радикала в катионе $\mathrm{Bu}_{4} \mathrm{~N}^{+}$ по сравнению c $\mathrm{Et}_{4} \mathrm{~N}^{+}$приводит к значительному увеличению структурно-динамического параметра, что свидетельствует о динамическом структурировании молекул растворителя возле иона тетрабутиламмония и увеличении сольвофобной сольватации $\mathrm{Bu}_{4} \mathrm{~N}^{+}$в сравнении с $\mathrm{Et}_{4} \mathrm{~N}^{+}$.

Константы ионной ассоциации обсуждены с позиции конкуренции между электростатическими и некулоновскими силами с использованием короткодействующего некулоновского потенциала. Увеличение констант ионной ассоциации в ряду $\mathrm{Bu}_{4} \mathrm{NBF}_{4}<\mathrm{Et}_{4} \mathrm{NBF}_{4}<\mathrm{Bu}_{4} \mathrm{NBr}<\mathrm{Et}_{4} \mathrm{NBr}$ объясняется увеличением вклада короткодействующих ион-молекулярных взаимодействий в межионное притяжение в дополнение к электростатической составляющей. Увеличение температуры усиливает ионную ассоциацию благодаря как электростатической, так и короткодействующей составляющей.

Ключевые слова: бромид тетраэтиламмония, бромид тетрабутиламмония, тетрафтороборат тетраэтиламмония, тетрафтороборат тетрабутиламмония, ацетонитрил, электрическая проводимость, константа ионной ассоциации, предельная молярная электрическая проводимость, короткодействующий межионный потенциал, микродинамика ионной сольватации.

О.М. Калугін, Е.В. Лукінова, Д.О. Новіков. Електрична провідність, йон-молекулярна ассоціація та міжйонні взаємодії у розчинах деяких тетралкіламмонієвих солей в ацетонітрилі: вплив йона та температури.

Харківський національний університет імені В.Н. Каразіна, хімічний факультет, кафедра неорганічної хімії, майдан Свободи, 4, Харків, 61022, Україна

В роботі наведені експериментальні дані 3 електричної провідності розчинів $\mathrm{Et}_{4} \mathrm{NBr}, \mathrm{Et}_{4} \mathrm{NBF}_{4}, \mathrm{Bu}_{4} \mathrm{NBr}^{\circ}$, $\mathrm{Bu}_{4} \mathrm{NBF}_{4}$ в ацетонітрилі в інтервалі молярної концентрації $2 \cdot 10^{-4}-1 \cdot 10^{-2}$ моль дм ${ }^{-3}$ при температурах $5-55^{\circ} \mathrm{C}$. Граничні молярні електропровідності та константи іонної асоціації розраховані за допомогою рівняння ЛіВітона для симетричних елетролітів. На підставі попереднього аналізу кондуктометричних даних було встановлено, що параметр найбільшого зближення практично не залежить від температури для всіх досліджених ацетонітрильних розчинів. Тому параметр найбільшого зближення був прийнятий як сума радіусів катіонів $\mathrm{i}$ аніонів для подальшої обробки кондуктометричних даних.

Значення граничних іонних провідностей $\mathrm{Br}^{-}, \mathrm{BF}_{4}^{-}, \mathrm{Et}_{4} \mathrm{~N}^{+}$та $\mathrm{Bu}_{4} \mathrm{~N}^{+}$, а також структурно-динамічного параметра йон-молекулярної взаємодії, що були отримані за експериментальними граничними молярними електропровідностями, були інтерпретовані в рамках підхода, запропонованого авторами [Kalugin O. N., Vjunnik I. N. Limiting ion conductance and dynamic structure of the solvent in electrolyte solution. Zh. Khim. Fiz. (Rus.) 1991,10 708-714]. Встановлено що подовження алкільного радикалу в катіоні $\mathrm{Bu}_{4} \mathrm{~N}^{+}$порівняно $3 \mathrm{Et}_{4} \mathrm{~N}^{+}$веде до значного зростанням структурно-динамічного параметра, що свідчить про динамічне структурування молекул розчинника біля йону тетрабутиламмонія та збільшенням сольвофобної сольватації $\mathrm{Bu}_{4} \mathrm{~N}^{+}$у порівнянні $3 \mathrm{Et}_{4} \mathrm{~N}^{+}$.

Константи йонної асоціації обговорені з позицій конкуренції між електростатичними та некулонівськими силами за допомогою короткодіючого некулонівського потенціала. Збільшення значень констант іонної асоціації у ряду $\mathrm{Bu}_{4} \mathrm{NBF}_{4}<\mathrm{Et}_{4} \mathrm{NBF}_{4}<\mathrm{Bu}_{4} \mathrm{NBr}<\mathrm{Et}_{4} \mathrm{NBr}$ пояснюється збільшенням внеску короткодіючих іон-молекулярних взаємодій в міжйонне притяжіння на додаток до електростатичної складової. Було встановлено, що збільшення температури посилює йонну ассоціацію завдяки як електростатичній, так і короткодіючій складовій.

Ключові слова: тетраетиламмоній бромід, тетрабутиламмоній бромід, тетраетиламмоній тетрафлуороборат, тетрабутиламмоній тетрафрлороборат, ацетонітрил, електрична провідність, константа йонної асоціації, гранична молярна електрична провідність, короткодіючий міжйонний потенціал, мікродинаміка йонної сольватації.

Kharkiv University Bulletin. Chemical Series. Issue 33 (56), 2019 